\title{
Silences Broken, Silences Kept: Gender and Sexuality in African-American History
}

\author{
MICHELE MITCHELL
}

'Even today,' Evelyn Brooks Higginbotham lamented in 1989, 'the black woman's voice goes largely unheard ... Afro-American history has failed to address gender issues adequately, while women's history has similarly failed to address questions of race'. African-American women's history was neither compensatory measure nor quaint sub-field according to Higginbotham. Rather, the inclusion of black women in historical analysis facilitated sophisticated theorising on the nexus of gender, power, and oppression; the acknowledgement that gender could not be separated out from race would, Higginbotham maintained, enable historians of US women to break away from what she termed a 'white, middle-class ... northeastern bias'. And, as more literature on black women was written, Higginbotham contended, it would become manifestly evident that gender history methodologies had something dynamic to offer African-American history as well. ${ }^{1}$

When Higginbotham's 'Beyond the Sound of Silence' appeared in the inaugural issue of Gender \& History, African-American women's history was well on its way to becoming an established field. Deborah Gray White had recently transformed the study of slavery by investigating women's networks and life cycles along with gendered divisions of labour and domestic relationships. Jacqueline Jones had already produced her magisterial survey of black women's labour and experience while Dolores Janiewski had powerfully analysed class, gender, and race in her study of black women tobacco workers. ${ }^{2}$ Pioneering work by Rosalyn Terborg-Penn, Sharon Harley, Andrea Benton Rushing, Paula Giddings, and Dorothy Sterling laid foundations for the field by providing analytical frameworks, methodologies, and source materials; landmark essays by Hazel Carby, Elsa Barkley Brown, and Darlene Clark Hine had either appeared or were in the offing. ${ }^{3}$ Still, all was not well. What Higginbotham found so unsettling - indeed, vexing was that African-American women remained marginal to interpretations of US history: US women's historians and African Americanists might have paid black women cursory attention, but other Americanists virtually ignored them. Higginbotham concluded that such oversights impoverished historiography, compromised the potential of gender analysis to uncover the 
complexities of women's lives, and frustrated attempts to 'explain the contradictory relationship of women and blacks to the American experience' ${ }^{4}$ Silence, in other words, had its consequences.

Happily, the discomfiting hush surrounding race and gender that Higginbotham identified has become a full-throated shout a mere decade later: women are no longer considered auxiliary or irrelevant to the AfricanAmerican past. Gender analysis has recast the ways we think about slavery, the era of Reconstruction, protest, and social movements; it has transformed our assumptions about political involvement, lynching, migration, urbanisation, and labour. Sexuality, in its own right, has emerged as a critical site of inquiry. ${ }^{5}$ Not only have many African Americanists and Americanists heeded the call to consider race and gender as integral to the writing of history, the very attention to gender Higginbotham and others longed for has led some scholars to explore manhood and masculinity. ${ }^{6}$ If, over the past ten years, gender historians have produced some of the most important monographs in US history, the same can certainly be said of AfricanAmerican history. 'Vibrant' hardly begins to characterise the field - books keep coming, articles appear with regularity, the production of dissertations proceeds apace.

However, in 1999, are there other causes for alarm, other reasons to lament? Whereas it would be useful and perhaps revealing to ask whether Americanists have met Higginbotham's challenge to analyse race and gender in tandem, it is more important to ponder whether African Americanists who theorise gender and sexuality have fomented new silences. Although I am not worried that the push to think of race and gender as interlocked has resulted in conflation of categories, much in AfricanAmerican history remains unsaid or barely articulated. I am, then, somewhat bothered by lurking suspicions that certain subjects are avoided because they have been deemed either dangerous or damaging. If on occasion we censor ourselves out of understandable desires not to fuel racist canards pertaining to alleged black pathologies, I am nonetheless uneasy about the costs attached to this particular quiet.

Scholars broached difficult topics such as rape, domestic violence, and sexism before and since Higginbotham's article was published. Still, which subjects have been largely avoided? Have those of us who work on AfricanAmerican history unwittingly limited the interpretative, analytic power of gender by steering clear of the explosive? Gender analysis has effectively complicated notions that there ever was a 'monolithic black community', but have we used it rigorously enough to uncover ways in which black communities - not to mention households, organisations, and movements - were fraught with tensions? On a slightly different point, what phenomena have influential, much-used concepts obscured? To borrow from Elsa Barkley Brown, just 'what has happened here'?

Though Higginbotham would soon publish another critical essay on the writing of US history after 'Beyond the Sound of Silence', perhaps an earlier 
essay was instrumental in starting a veritable revolution within AfricanAmericanist circles. ${ }^{8}$ James Horton's breakthrough article on gender conventions among free blacks during the antebellum era was published in 1986 and accomplished something not even Higginbotham called for: it deftly considered both manhood and womanhood as it uncovered how antebellum Afro-American journals typically 'preached the gospel of continued gender oppression even as they supported the struggle for racial freedom' ${ }^{9}$ Horton illuminated how race was inseparable from gender by demonstrating that bondage had a profound effect on black gender roles, that free people's decisions to follow conventions of the larger society were at once liberating and limiting. Not only was he sensitive to power dynamics between African-American men and women, Horton came to incisive conclusions about how the longing of black men to seize the prerogatives of manhood denied them by the larger society could and did stultify black women's own desires. Overall, 'Freedom's Yoke' was a notable departure in the existing literature since most African Americanists at the time focused primarily upon women as did other scholars whose labours established gender history.

Horton's work offered an outstanding analysis that would influence other initial essays in African-Americanist gender history, including Sharon Harley's important article on work and domestic roles in black communities. ${ }^{10}$ The deployment of feminist theory evident in Horton would, as the field developed, repeatedly confound notions that there ever was a time when gender politics did not affect black communities or when the interests of black men and women were always in harmony. 'Difference', then, was not only a meaningful concept for women's studies, feminist theory, and US history but could say much about intra-racial dynamics. ${ }^{11}$

Four years after 'Freedom's Yoke' appeared in print, E. Frances White pushed the analysis of gender politics further. With empathetic yet unflinching aplomb, White assessed ways in which African-American nationalist discourse contained sexist and homophobic elements. Black nationalism was a powerful oppositional discourse, but, as White warned, it could also be profoundly conservative when it came to gendered expectations about how members of the collective should interact or with whom they should make love. ${ }^{12}$ 'Africa on My Mind' was more than a muchneeded history of the fallout between feminists and nationalists during the 1970s: White produced a discursive study that dramatised the impact of ideas on people's daily lives. As Hazel Carby, Barbara Bair, and Elsa Barkley Brown would accomplish in short order, White revealed deep, competing interests between men and women - indeed, between women. ${ }^{13}$ And, as Bair's work did two years later, White revealed why ideologies 'against which many ... white feminists revolted' could be appealing for some black women. ${ }^{14}$

White's treatment of twentieth-century black nationalist discourse and its complicated deployment of ideas regarding gender and sexuality would 
soon be followed by two assessments of racialised gender ideologies a century earlier. In one of the first extended gender analyses focused upon black men, Jim Cullen convincingly portrayed the Civil War as a 'watershed for black manhood' that altered gender conventions in AfricanAmerican communities so that they more closely resembled those of whites'. He traced the usage of muscular rhetoric among African-American men as he vivified reasons why cultural acknowledgement of black manliness was so important to ex-slaves and freedmen alike. Cullen said little about the domestic conflict that probably occurred when soldiers returned from war determined to assert their new-found sense of authority at home, but 'I's a Man Now' did suggest that the postbellum reorientation of gender dynamics among black Americans was both marked and profound. Significantly, Cullen cited Gail Bederman whose work on race, manliness, and notions of civilisation would yield a major article on the 1892-4 antilynching campaign of Ida B. Wells. Wells was arguably the most effective crusader against the murderous racial terrorism of her day; she knew how to seize upon 'the Northern middle class's widespread fears about declining male power' in order to 'convinc[e] nervous whites that lynching imperiled American manhood'. In print and on the podium, Wells proclaimed that black men embodied manhood, that the progress made by African Americans in less than thirty years of freedom epitomised civilisation. By focusing upon Wells's skilful manipulation of gender and race, Bederman constructed a breathtaking narrative of how members of an oppressed people transform dominant discourses into counter-discourses. Bederman's close attention to the historical context surrounding a notorious system of oppression further enabled her to capture how competing racialised and classed notions of gender operate simultaneously. ${ }^{15}$

Just as Horton's efforts helped introduce a vital methodology to AfricanAmerican history, White offered one of the most striking statements to date, and gender analysis was pushed in new directions by Cullen and Bederman, two concepts introduced by Darlene Hine and Evelyn Higginbotham assisted the maturation of African-Americanist gender history and dominated the field. The notion that African-American women developed a code of silence around intimate matters as a response to discursive and literal attacks on black sexuality has influenced studies of turn-of-the-century club women, reformers, and workers ever since Darlene Clark Hine labelled this practice the 'culture of dissemblance' in 1989. ${ }^{16}$ Hine argued that, after slavery, routine sexual assault and pervasive stereotypes about black female sexuality prompted women of African descent to shroud sensual aspects of their persons from public view. If popular notions about lewd, lascivious 'negroes' justified ritualised rape then black women assumed some control over a noxious situation by protecting their 'inner lives and selves' through a selective revelation of the personal that 'created the appearance of ... disclosure'. ${ }^{17}$ This strategy not only made employment in white households tolerable for domestic workers who faced on-the-job harassment, it shaped 
most daily interactions and informed the flurry of institution building by activist women.

As a concept deployed by historians of gender and sexuality, the 'culture of dissemblance' has been inordinately useful in explaining the motives of women who migrated out of southern states in order to find various forms of social autonomy. Dissemblance has helped us understand why a significant cohort of black women who were, in many respects, 'New Women', did not indulge in late nineteenth- and early twentieth-century social emancipations to the same extent as their white peers. It has enriched our understanding of class in African-American communities in that dissemblance underscores how sexual comportment was integral to the class identities of aspiring-class and elite people. The reality that many black women found it useful to dissemble has provided critical clues about how aspiring-class and elite parents reared their daughters. Moreover, we are now better able to assess how black women and men have consistently engaged practices of dissemblance in order to 'survive in a racialized world not of their own making'. ${ }^{18}$

Embracing the concept of dissemblance even helped Evelyn Higginbotham interpret how black women guarded their sexuality as part of a 'politics of respectability'. ${ }^{19}$ Although scholars such as Willard Gatewood, Wilson Jeremiah Moses, and E. Frances White had already written on the significance of controlled morality to the black elite and to nationalists, it was Higginbotham who provided analytical language that would guide future work. ${ }^{20}$ Higginbotham elaborated upon existing literature in that she limned salient connections between desires of post-emancipation African Americans - particularly those in the aspiring and elite classes - to appear 'respectable' and attempts by women activists to bring about collective improvement. Building upon a wealth of existing work on intra-racial reform, Higginbotham's Righteous Discontent was part of an ongoing mission to demonstrate how central women and gender were to understanding key aspects of the decades following emancipation. ${ }^{21}$

Beyond matters of sexual behaviour, comportment, dress, and leisure, a sizeable cohort of African Americans during the late nineteenth and early twentieth centuries expected members of the race to maintain upright appearances in households, family matters, seats of learning, and workplaces. Higginbotham's analysis of this phenomenon echoed E. Frances White's observation that intra-racial politics could be simultaneously emancipatory and oppressive: if notions about respectability were a politicised insistence 'upon [the race's] conformity to the dominant society's norms of manners and morals' and if black women could use this form of personal politics as a 'powerful weapon of resistance to race and gender subordination', those same notions also led reformers to behave in problematic ways towards the working poor on occasion. ${ }^{22}$ Certainly, some workers, sharecroppers, and recent migrants to cities welcomed activists' attempts to facilitate racial uplift; other workers, sharecroppers, and migrants, 
however, undoubtedly felt more like targets and less like agents of reform initiatives.

Historians such as Hazel Carby and Christina Simmons came to similar conclusions about class, sexuality, and African-American reform activism within a year of Righteous Discontent's publication. ${ }^{23}$ Even scholars who came to different conclusions dealt with the politics of respectability either implicitly or explicitly. In her study of household labourers, Tera Hunter offered compelling evidence that in leisure settings black domestics were not concerned with hiding their sexuality or acting genteel. Victoria Wolcott, on the other hand, demonstrated that respectability held a certain currency for working-class elders concerned about the chastity of daughters, nieces, and granddaughters; she also stressed that meanings and practices of respectability were not the same for all women. ${ }^{24}$

'Respectability', then, resonated with the concentration of scholars working on the late nineteenth and early twentieth centuries. Conceptually, the politics of respectability was not only part of a historiographical turn towards class and intra-racial dynamics, it coincided with greater numbers of African Americanists doing work on the history of sexuality. Historians produced work touching upon or exploring black sexuality before publication of Righteous Discontent - Nell Painter examined 'miscegenation, labor, and power' while Eric Garber's article on the Harlem Renaissance was an early foray into African-American gay and lesbian history ${ }^{25}$ - but it was not until the early and mid 1990s that scholars started to write on black sexuality in earnest. Arguably, Righteous Discontent and essays such as Simmons's 'African Americans and Sexual Victorianism' enabled this shift as did the 1988 publication of D'Emilio and Freedman's Intimate Matters and the pointed response it evoked from literary scholar Ann du Cille. ${ }^{26}$

More specifically, African-Americanist work on the history of sexuality has developed rapidly since du Cille charged D'Emilio and Freedman with giving people of colour short shrift in their landmark study of sexuality in the US. Between 1993 and 1997 alone, historians published articles regarding slave children and sexual identity, an erotic relationship between two free women, and white Southerners' anxieties about black male sexuality during Reconstruction. Analyses of inter-racial couplings have emerged as well. For example, Kevin Mumford's monograph on early twentieth-century urban 'interzones' describes how a range of Americans crossed the colour line in search of sundry carnal pleasures as it reveals how black city dwellers broke with convention and flaunted behaviours that social purity reformers considered degenerate. ${ }^{27}$ Not only is Mumford's work provocative, he is part of a new cohort of scholars who are furthering our understanding of how time and place shape individual and collective reactions to sexual 'race-mixing'. Given that the US has been a nation obsessed with racial boundaries throughout much if not most of its existence, their contributions to the field are both welcome and needed. ${ }^{28}$ Work on other aspects of African Americans' sexuality also have something to offer US 
historiography, including a forthcoming dissertation on the sexual terrorism enacted upon black women after the Civil War and another on AfricanAmerican sex workers in the early decades of the twentieth century. Additionally, recent dissertations explore enslaved women's reproductive labour during the seventeenth and eighteenth centuries, discuss African Americans' concepts about racial reproduction during the Progressive Era, and analyse gendered struggle within the Black Panther Party. These dissertations should broaden our knowledge about mob violence and prostitution and expand what we know about slavery, popular eugenics, and sexual dynamics within political movements. ${ }^{29}$

Over the past decade, African Americanist gender history has consistently noted how specific phenomena - subjugation, racist discourse, attempts to realise collective improvement, initiatives for community mobilisation, longings for self-determination, desires to break free from social strictures - spurred black women and men to seize or alter mainstream gender conventions. Attention to gender and sexuality has added considerable nuance to how we analyse the convergence and divergence of African Americans' experiences with and from the experiences of other ethnic groups in the US. We better appreciate the remarkable variety of African Americans' lives and communities over the course of US history because of questions asked by gender scholars.

In terms of what African-Americanist scholarship can yet accomplish, Elsa Barkley Brown made an observation in 1995 that bears repetition now: she has heard few 'people question the notion that lynching ... is a masculine experience'. Brown's remark sounds a tocsin as it reminds us that assumptions perpetuate silences. If African Americanists have done little work on the lynching of black women, scholars in the field have also neglected to ask whether decreases in post-emancipation birth rates were in any way connected to changes in males' sexual practices. Much can still be gained, then, by interrogating our own assumptions and conclusions. ${ }^{30}$

This is not to suggest that no one is engaged in the work of reconceptualisation. For example, scholars who consider African Americans alongside other people from non-majority US populations or within the Black Atlantic world are currently reorienting the field. As this trend continues, perhaps historians shall start writing about black men in conjunction with other men of colour; hopefully, this will occur since studies of black men, manhood, and masculinity are few in number. Moreover, what can we discover about social reform by juxtaposing sex reform efforts among African Americans to those among Native Americans? What can be revealed about leisure, urbanisation, and sexual self-presentation if black Americans are discussed together with Afro-Cubans? What can we find out about processes of oppression by analysing gendered forms of violence towards Mexican Americans, Asian Americans, and African Americans in tandem? What more can we reveal about gender, sexuality, and social movements by doing comparative work on African Americans 
and Afro-Brazilians? These groupings are random but nonetheless suggest the range of work that is possible. The turn towards the Black Atlantic might, for example, lead African Americanists to write more histories of medicine and craft different narratives about gender and religion.

In addition, it remains crucial to consider how analytical frameworks can obscure as well as reveal. In terms of sexuality, concepts regarding dissemblance and respectability have facilitated much important work about reform, institution building, and their relationship to class formation; those same concepts have not, however, generated African-Americanist work on gay and lesbian history. Similarly, no two concepts can generate all the questions that need to be asked about intra-racial relationships, reproductive concerns, or the variety of ways sexuality informed, complicated, and enriched African Americans' lives. Since recent work on sexuality is pushing the field in new directions and because more African Americanists are engaged in comparative analyses, the conceptual landscape shall certainly expand over the next ten years.

During the next decade historians might break lingering silences as well. In addition to needing more histories that engage the spectrum of African Americans' sexual identities and more studies on children, further investigation into how, why, and when black women and men have been at odds is necessary. In particular, we need to know more about conflicts that occur outside of organised protest. African Americanists have consistently acknowledged hierarchies; scholars have made pathbreaking contributions by examining conflicts between women, between men. Still, writing about clashes between black women and men remains somewhat prickly because themes of collective survival, community mobilisation, and institution building are of signal importance to the field. Moreover, examining gendered strife is potentially explosive since African Americans are still hounded by notions that gender, domestic, and sexual relationships between black women and men are warped, pathological. That acknowledged, staying quiet will hardly eradicate such notions - silence might actually enable them.

Just as African Americans are now analysing intra-racial class tensions with nuance - and are increasingly doing so with issues surrounding colour - there is little reason why research on intra-racial gender conflicts that occur beyond organisational life can not be conducted in similar fashion. If the eloquence of gender history is its very ability to elaborate upon both expressed and inchoate discourses of power, then why not explore conflict as a means of exploding the sway of racialised discourse? If gender analysis can say volumes about how power operates in quotidian life, then why should we avoid rigorous examination of the power dynamics between black women and men in households, on work-sites, in public spaces? Exploring conflict in all of its aspects might be uncomfortable for many historians working in the field, but certainly no more so than our being plagued by the haunting, redounding echo of an uneasy silence. 


\section{Notes}

1. Evelyn Brooks Higginbotham, 'Beyond the Sound of Silence: Afro-American Women in History', Gender \& History, 1 (1989), pp. 50-67, esp. pp. 50, 52, 60.

2. Deborah Gray White, Ar'n't I A Woman?: Female Slaves in the Plantation South (W. W. Norton \& Company, New York, 1985); Jacqueline Jones, Labor of Love, Labor of Sorrow: Black Women, Work, and the Family from Slavery to the Present (Basic Books, Inc., New York, 1985); Dolores Janiewski, Sisterhood Denied: Race, Gender, and Class in a New South Community (Temple University Press, Philadelphia, 1986).

3. Rosalyn Terborg-Penn, 'Discontented Black Feminists: Prelude and Postscript to the Passage of the Nineteenth Amendment', in Decades of Discontent: The Women's Movement, ed. Lois Sharf and Joan M. Jensen (Greenwood Press, Westport, CT, 1983); Rosalyn Terborg-Penn, Sharon Harley, and Andrea Benton Rushing (eds), Women in Africa and the African Diaspora (Howard University Press, Washington, DC, 1987); Paula Giddings, When and Where I Enter: The Impact of Black Women on Race and Sex in America (Morrow, New York, 1984); Dorothy Sterling, We Are Your Sisters: Black Women in the Nineteenth Century (W. W. Norton \& Company, New York, 1984); Hazel V. Carby, "'On the Threshold of Woman's Era": Lynching, Empire, and Sexuality in Black Feminist Theory', Critical Inquiry, 12 (1985), pp. 262-77; Hazel V. Carby, "It Jus Be's Dat Way Sometime": The Sexual Politics of Women's Blues', Radical America, 20 (1986), pp. 9-22; Elsa Barkley Brown, 'Womanist Consciousness: Maggie Lena Walker and the Independent Order of Saint Luke', Signs, 14 (1989), pp. 610-33; Darlene Clark Hine, 'Rape and the Inner Lives of Black Women in the Middle West: Preliminary Thoughts on the Culture of Dissemblance', Signs, 14 (1989), pp. 912-20.

4. Higginbotham, 'Beyond the Sound of Silence', p. 63.

5. Kathleen M. Brown, Good Wives, Nasty Wenches, and Anxious Patriarchs: Gender, Race, and Power in Colonial Virginia (University of North Carolina Press, Chapel Hill, 1996); Susan Juster and Lisa MacFarlane (eds), A Mighty Baptism: Race, Gender, and the Creation of American Protestantism (Cornell University Press, Ithaca and London, 1996); Amy Dru Stanley, From Bondage to Contract: Wage Labor, Marriage, and the Market in the Age of Slave Emancipation (Cambridge University Press, Cambridge, 1998); Leslie A. Schwalm, A Hard Fight for We: Women's Transition from Slavery to Freedom in South Carolina (University of Illinois Press, Urbana, 1997); Laura F. Edwards, Gendered Strife and Confusion: The Political Culture of Reconstruction (University of Illinois Press, Urbana, 1997); Beryl Satter, 'Marcus Garvey, Father Divine, and the Gender Politics of Race Difference and Race Neutrality', American Quarterly, 48 (1996), pp. 43-76; Susan L. Smith, Sick and Tired of Being Sick and Tired: Black Women's Health Activism in America, 1890-1950 (University of Pennsylvania Press, Philadelphia, 1995); Glenda Elizabeth Gilmore, Gender \& Jim Crow: Women and the Politics of White Supremacy in North Carolina, 1896-1920 (University of North Carolina Press, Chapel Hill, 1996); Gail Bederman, Manliness and Civilization: A Cultural History of Gender and Race in the United States, 1880-1917 (University of Chicago Press, Chicago and London, 1995); Elsa Barkley Brown, 'Imaging Lynching: African American Women, Communities of Struggle, and Collective Memory', in African American Women Speak Out on Anita Hill-Clarence Thomas, ed. Geneva Smitherman (Wayne State University Press, Detroit, 1995), pp. 100124; Darlene Clark Hine, 'Black Migration to the Urban Midwest: The Gender Dimension, 1915-1945', in The Great Migration in Historical Perspective: New Dimensions of Race, Class, \& Gender (Indiana University Press, Bloomington, 1991), pp. 127-46; Gretchen Lemke-Santangelo, Abiding Courage: African American Migrant Women and 
the East Bay Community (University of North Carolina Press, Chapel Hill, 1996); Tera W. Hunter, To 'Joy My Freedom: Southern Black Women's Lives and Labors after the Civil War (Harvard University Press, Cambridge and London, 1997); Elizabeth Lapovsky Kennedy and Madeline D. Davis, Boots of Leather, Slippers of Gold: The History of a Lesbian Community (Routledge, New York, 1993); Martha Hodes, White Women, Black Men: Illicit Sex in the Nineteenth Century South (Yale University Press, New Haven and London, 1997).

See also Martin Anthony Summers, 'Nationalism, Race Consciousness, and the Constructions of Black Middle Class Masculinity During the New Negro Era, 1915-1930' (PhD diss., Rutgers University, 1997); Premilla Nadasen, 'The Welfare Rights Movement in the United States, 1960-1975' (Columbia University, PhD diss., 1999); M. Elaine Roland, 'A Land Where You Can Be Free: Gender, Black Nationalism, and the All-Black Towns of Oklahoma' (PhD diss., University of Michigan, forthcoming).

As testimony to developments in US historiography, not all of the above works deal exclusively with African Americans.

6. See, for example, James Oliver Horton, Free People of Color: Inside the African American Community (Smithsonian Institution Press, Washington, DC, 1993); Harry Stecopoulos and Michael Uebel (eds), Race and the Subject of Masculinities (Duke University Press, Durham and London, 1997); and Darlene Clark Hine and Earnestine Jenkins (eds), A Question of Manhood: A Reader in US Black Men's History and Masculinity (Indiana University Press, Bloomington, 1999).

7. Higginbotham, 'Beyond the Sound of Silence', p. 63; Elsa Barkley Brown, "WWhat Has Happened Here": The Politics of Difference in Women's History and Feminist Politics', Feminist Studies, 18 (1992), pp. 295-312.

8. Evelyn Brooks Higginbotham, 'African-American Women's History and the Metalanguage of Race', Signs, 17 (1992), pp. 251-74.

9. James Oliver Horton, 'Freedom's Yoke: Gender Conventions Among Antebellum Free Blacks', Feminist Studies, 12 (1986), pp. 51-76, esp. p. 74. A contemporary analysis of African-American manhood is David Leverenz's discussion of Frederick Douglass in Leverenz, Manhood and the American Renaissance (Cornell University Press, Ithaca and London, 1989), pp. 108-34.

10. Sharon Harley, 'For the Good of Family and Race: Gender, Work, and Domestic Roles in the Black Community, 1880-1930', Signs, 15 (1990), pp. 336-49, esp. p. 337, n. 1.

11. Brown, "What Has Happened Here"'; Higginbotham, 'African-American Women's History and the Metalanguage of Race'.

12. E. Frances White, 'Africa on My Mind: Gender, Counter Discourse and AfricanAmerican Nationalism', Journal of Women's History, 2 (1990), pp. 73-97, esp. pp. 76-7, 93-4.

13. Hazel V. Carby, 'Policing the Black Woman's Body in an Urban Context', Critical Inquiry, 18 (1992), pp. 738-55; Barbara Bair, 'True Women, Real Men: Gender, Ideology, and Social Roles in the Garvey Movement', in Gendered Domains: Rethinking Public and Private in Women's History, ed. Dorothy O. Helly and Susan Reverby (Cornell University Press, Ithaca, 1992), pp. 154-66; Elsa Barkley Brown, Negotiating and Transforming the Public Sphere: African American Political Life in the Transition from Slavery to Freedom', Public Culture, 7 (1994), pp. 107-46.

14. Bair, 'True Women, Real Men', p. 156; White, 'Africa on My Mind', pp. 86-90.

15. Jim Cullen, "I's a Man Now": Gender and African American Men', in Divided Houses: Gender and the Civil War, ed. Catherine Clinton and Nina Silber (Oxford University Press, New York, 1992), pp. 76-91, esp. pp. 77, 90; Gail Bederman, 
"'Civilization," the Decline of Middle-Class Manliness, and Ida B. Wells's Antilynching Campaign (1892-94)', Radical History Review, 52 (1992), pp. 5-30, esp. pp. 5-6, $11-14,22$.

16. Hine, 'Rape and the Inner Lives of Black Women'.

17. Hine, 'Rape and the Inner Lives of Black Women', pp. 912, 915.

18. Hine, 'Rape and the Inner Lives of Black Women'; Christina Simmons, 'African Americans and Sexual Victorianism in the Social Hygiene Movement, 1910-1940', Journal of the History of Sexuality, 4 (1993), pp. 51-75; Deborah Gray White, Too Heavy a Load: Black Women in Defense of Themselves, 1894-1994 (W. W. Norton \& Company, New York and London, 1999), pp. 87-141, esp. 87-8, 124-30; Stephanie Shaw, What a Woman Ought to Be and to Do: Black Professional Women Workers During the Jim Crow Era (University of Chicago Press, Chicago and London, 1996), pp. 13-40, esp. pp. 23-4; Kevin K. Gaines, Uplifting the Race: Black Leadership, Politics, and Culture in the Twentieth Century (University of North Carolina Press, Chapel Hill, 1996), pp. 5-9, esp. p. 5.

Here, I use 'aspiring class' because I find 'middle class' to be a particularly unsatisfactory term to describe post-Reconstruction era African-Americans. 'Aspiring class' refers to folk - many were self-educated, had a normal school education, or attended college - who worked for a living and were able to save a portion of their earnings and perhaps acquire property. What distinguishes these African Americans from industrial age bourgeoisie is that the socio-economic standing of aspiring-class people was somewhat more tenuous: economic downturn or personal calamity was likely to move an aspiring-class person into poverty, not the working class.

19. Evelyn Brooks Higginbotham, Righteous Discontent: The Women's Movement in the Black Baptist Church, 1880-1920 (Harvard University Press, Cambridge and London, 1993), pp. 185-229, esp. pp. 193-4.

20. Willard Gatewood, Aristocrats of Color: The Black Elite, 1880-1920 (Indiana University Press, Bloomington, 1990), pp. 182-209; Wilson Jeremiah Moses, 'Sexual Anxieties of the Black Bourgeoisie in Victorian America: The Cultural Context of W. E. B. Du Bois' First Novel', Western Journal of Black Studies, 4 (1982), pp. 202-11; White, 'Africa on My Mind', pp. 76-7.

21. Cynthia Neverdon-Morton, Afro-American Women of the South and the Advancement of the Race, 1895-1925 (University of Tennessee Press, Knoxville, 1989); Dorothy Salem, To Better Our World: Black Women in Organized Reform, 1890-1920 (Carlson Publishing, Brooklyn, 1990); Beverly Guy-Sheftall, Daughters of Sorrow: Attitudes Toward Black Women, 1880-1920 (Carlson Publishing, Brooklyn, 1990).

22. Higginbotham, Righteous Discontent, pp. 187, 198-204, 227. For insightful commentary on uplift politics and its gendered components, see Gaines, Uplifting the Race.

23. Carby, 'Policing the Black Woman's Body'; Simmons, 'African Americans and Sexual Victorianism'.

24. Hunter, To 'Joy My Freedom, esp. pp. 168-86; Victoria W. Wolcott, "Bible, Bath and Broom": Nannie Helen Burrough's National Training School and African-American Racial Uplift', Journal of Women's History, 9 (1997), pp. 88-110; Victoria W. Wolcott, 'Remaking Respectability: African-American Women and the Politics of Identity in Interwar Detroit' (University of Michigan, PhD diss., 1995). For yet another take on respectability, see Amy Jordan, 'Extending the Organizing Tradition: Welfare Rights and the Politics of Respectability' (University of Michigan, PhD diss., 1999).

25. Nell Irvin Painter, "Social Equality," Miscegenation, Labor, and Power', in The Evolution of Southern Culture, ed. Numan V. Bartley (University of Georgia Press, 
Athens, 1988), pp. 47-67; Eric Garber, 'A Spectacle in Color: The Lesbian and Gay Subculture of Jazz Age Harlem', in Hidden From History: Reclaiming the Gay and Lesbian Past, ed. Martin Bauml Duberman, Martha Vicinus and George Chauncey, Jr (New American Library, New York, 1989), pp. 318-31.

26. John D'Emilio and Estelle B. Freedman, Intimate Matters: A History of Sexuality in America (Harper \& Row Publishers, New York, 1988); Ann du Cille, "Othered" Matters: Reconceptualizing Dominance and Difference in the History of Sexuality in America', Journal of the History of Sexuality, 1 (1990), pp. 102-27.

27. Anthony S. Parent, Jr, and Susan Brown Wallace, 'Childhood and Sexual Identity under Slavery', Journal of the History of Sexuality, 3 (1993), pp. 363-401; Martha Hodes, 'The Sexualization of Reconstruction Politics: White Women and Black Men in the South after the Civil War', Journal of the History of Sexuality, 3 (1993), pp. 402-17; Kevin J. Mumford, Interzones: Black/White Sex Districts in Chicago and New York in the Early Twentieth Century (Columbia University Press, New York, 1997).

28. The following articles are representative of new work in the field: Graham Russell Hodges, 'The Pastor and the Prostitute: Sexual Power among African Americans and Germans in Colonial New York', in Sex, Love, Race: Crossing Boundaries in North American History, ed. Martha Hodes (New York University Press, New York, 1999); Leslie M. Harris, 'From Abolitionist Amalgamators to "Rulers of the Five Points": The Discourse of Interracial Sex and Reform in Antebellum New York City', Sex, Love, Race, pp. 191-212; Daniel R. Mandell, 'The Saga of Sarah Muckamugg: Indian and African American Intermarriage in Colonial New England', Sex, Love, Race, pp. 72-90; Jonathan Zimmerman, 'Crossing Oceans, Crossing Colors: Black Peace Corps Volunteers and Interracial Love in Africa, 1961-1971', Sex, Love, Race, pp. 514-30.

29. Hannah Rosen is writing a history of postbellum sexual violence (University of Chicago, PhD diss., forthcoming) while Cynthia Blair is writing on black women sex workers in Chicago (Harvard University, PhD diss., forthcoming). The recent dissertations referred to in the text are: Jennifer Lyle Morgan, 'Laboring Women: Enslaved Women, Reproduction, and Slavery in Barbados and South Carolina, 1650-1750' (Duke University, PhD diss., 1995); Michele Mitchell, 'Adjusting the Race: Gender, Sexuality, and the Question of African-American Destiny, 1877-1930' (Northwestern University, PhD diss., 1998); Tracye Ann Matthews, "'No One Ever Asks What a Man's Place in the Revolution Is": Gender and Sexual Politics in the Black Panther Party, 1966-1971' (University of Michigan, PhD diss., 1998).

See also Jennifer L. Morgan, "Some Could Suckle over Their Shoulder": Male Travelers, Female Bodies, and the Gendering of Racial Ideology, 1500-1770', William and Mary Quarterly, 54 (1997), pp. 167-92; Hannah Rosen, "Not That Sort of Women": Race, Gender, and Sexual Violence during the Memphis Riot of 1866', Sex, Love, Race, pp. 267-93.

30. Brown, 'Imaging Lynching', pp. 100-2.

For an example of the promise of such reconceptualisation, see Marilynn S. Johnson, 'Gender, Race, and Rumours: Re-examining the 1943 Race Riots', Gender \& History, 10 (1998), pp. 252-77. 